\title{
BRAND ASSOCIATION PERGURUAN TINGGI JAWA BARAT MENGHADAPI PERSAINGAN MASYARAKAT EKONOMI ASEAN (MEA) DAN DUNIA
}

\author{
Rahmat Gunawan \\ Program Studi Managemen Fakultas Ekonomi Universitas Djuanda Bogor \\ Email : rahmat.gunawan@unida.ac.id
}

\begin{abstract}
The condition of State and Private Universities in Indonesia, especially West Java, is connected with the condition of universities in the world is still very alarming. PTN and PTS rankings in Indonesia and West Java in particular are still far from expectations. West Java Higher Education Position for world level still not able to occupy the rank of 100 magnitude. Still far from the top 50 positions. Even to the level of Asia although not many PT in Indonesia especially West Java which is able to occupy the top 50 rankings. In ASEAN only UI is able to rank 6th ASEAN. The others are far from expectations. The phenomenon of such problems need to be explored and sought by the solution so that Indonesian universities in West Java can advance in the competition among PT in the world, especially ASEAN and Asia so as to increase the competitiveness of Indonesian nation in the competition of nations in the world.
\end{abstract}

Keywords: Universities, Competitiveness, Asean Economic Community

\begin{abstract}
ABSTRAK
Kondisi Perguruan Tinggi Negeri dan Swasta di Indonesia khususnya Jawa Barat dihubungkan dengan kondisi Perguruan Tinggi di dunia masih sangat memprihatinkan. Rangking PTN dan PTS di Indonesia dan Jawa Barat khususnya masih jauh dari harapan. Posisi Perguruan Tinggi Jawa Barat untuk tingkat dunia masih belum mampu menempati rangking 100 besaran. Masih jauh dari posisi 50 besar. Bahkan untuk tingkat Asia sekalipun belum banyak PT di Indonesia khusunya Jawa Barat yang mampu menempati rangking 50 besar. Di ASEAN hanya UI yang mampu menempati peringkat 6 se ASEAN. Yang lainnya masih jauh dari harapan. Fenomena permasalahan seperti ini perlu digali dan dicari solusinya agar Perguruan Tinggi Indonesia di Jawa Barat mampu maju dalam persaingan antar PT di dunia khususnya ASEAN dan Asia sehingga mampu meningkatkan daya saing bangsa Indonesia dalam persaingan bangsa-bangsa di dunia.
\end{abstract}

Kata Kunci: Perguruan Tinggi, Daya Saing, Masyarakat Ekonomi ASEAN.

\section{PENDAHULUAN}

Berdasarkan survey pada tahun 2017, kondisi dunia pendidikan tinggi Indonesia khususnya di Jawa Barat dalam beberapa tahun terakhir di era MEA atau Masyarakat Ekonomi ASEAN terutama yang berlokasi di wilayah Priangan Timur dan Bogor Raya banyak yang mengalami kesulitan dalam mendapatkan mahasiswa baru Selain itu juga kesulitan dalam mendapatkan SDM dosen profesional yang semakin sulit didapatkan karena jumlahnya semakin langka mengingat adanya aturan Kemristek Dikti yang semakin ketat terhadap rasio jumlah dosen dengan jumlah mahasiswa membuat jumlah dosen yang ada sudah terikat pada berbagai perguruan tinggi secara tetap. Kondisi ini diperburuk oleh adanya fenomena lain berupa banyaknya PTN yang memperluas kapasitas penerimaan mahasiswa barunya, baik pada program D3 maupun program S1-nya.

Selain itu juga dengan adanya fenomena berupa kehadiran Masyarakat Ekonomi ASEAN dalam kehidupan sehari-hari Masyarakat Indonesia akibat adanya globalisasi kehidupan tidak terkecuali kehidupan dalam pendidikan tinggi di Indonesia yang menimbulkan kondisi persaingan yang semakin sengit antar PT 
dalam negeri maupun dengan PT Negara ASEAN lainnya yang notabene PT dari Negara ASEAN yang lainnya tersebut sudah ada yang berstandar dunia dihadapkan dengan kondisi PT di Indonesia yang masih kekurangan sumber daya.

Hal ini mengakibatkan beberapa PTS tertentu ada yang mengalami kekurangan jumlah mahasiswa sehingga terpaksa ditutup atau pun kalau tidak ditutup juga hidupnya tidak menentu akibat kekurangan jumlah mahasiswa dan kalah bersaing di pasar input di lingkungan eksternalnya sehingga untuk menutupi biaya operasionalpun juga sampai tidak mampu dan menyebabkan kerugian yang sangat besar. Selain itu banyak PTS yang kekurangan dosen di berbagai program studinya, khususnya program studi manajemen dan akuntansi akibat kalah bersaing dalam menarik para dosen baru untuk menjadi dosen tetap sebagai pasar internalnya. Tentunya kondisi semacam ini tidak diharapkan muncul karena dampak yang diakibatkan berefek domino sangat luas dan menyebabkan kerugian yang sangat besar bagi masyarakat dan negara khususnya yang berkaitan dengan kehilangan peran perguruan tinggi swasta yang ikut membantu pemerintah dalam pengelolaan program pendidikan tinggi bagi masyarakat luas yang selama ini tidak mampu diemban sendirian oleh perguruan tinggi negeri

Berkaitan dengan era persaingan MEA yang seharusnya berbagai PT Indonesia di Jawa Barat ini diharapkan bukannya tenggelam tapi muncul berprestasi ke tingkat ASEAN, Asia bahkan tingkat dunia untuk mendorong peningkatan daya saing Indonesia menghadapi persaingan di dunia. Nah untuk mendapatkan informasi tentang dunia PT di Indonesia khususnya Jawa Barat di Bogor Raya dan Priangan Timur dapat kita simak dari penjelasan di bawah ini.

\section{MATERI DAN METODE}

Sampai saat ini yang terjadi di berbagai PTS Indonesia khususnya Jawa Barat bahwa para pengelola PT khususnya PTS mulai gelisah mempertahankan kelangsungan hidupnya karena adanya fenomena masalah berupa Pembukaan program studi khususnya akuntansi dan manajemen di PTN yang mulai memperbesar kuota penerimaan mahasiswa barunya selain persaingan antar PT dalam memperebutkan dosen tetap baru yang konsekuensinya mereka harus bersaing ketat dan berusaha semaksimal mungkin untuk mempertahankan dan mendapatkan jumlah mahasiswa lebih banyak dari pihak pihak pesaingnya Selain itu juga mereka bersaing sengit selain untuk mendapatkan dosen baru juga mempertahankan para dosen lamanya yang hendak ditarik PTS yang lainnya karena adanya kelangkaan jumlah dosen professional khususnya di bidang ilmu akuntansi dan manajemen. Pertarungan mempertahankan dan merebut calon di pasar input ini memang terlihat ketat di dunia pendidikan tinggi saat ini. Langkah-langkah yang dilaksanakan oleh pihak PTS sebagian besar dengan menerapkan bauran pemasaran jasa yang didefiniskan sebagai konsep bauran pemasaran tradisional berupa produk, harga, tempat dan promosi khusus produk barang dan untuk produk jasa ditambah antara lain proses, orang dan bukti fisik seperti yang telah dijelasan oleh Zethaml dan Bitner dalam bukunya Pemasaran Jasa (2010) yang diaplikasikan dengan memberikan berbagai macam tawaran produk dan fasilitas yang menarik seperti mulai dari mengotak-atik biaya pendidikan agar terlihat lebih murah, mempublikasikan sejumlah nama pengajar terkenal, memberikan fasilitas perkuliahan yang menarik yang dimulai dari gedung yang baru, fasilitas pembelajaran yang lengkap dari laptop sampai LCD terbaru, kuliah berasrama, kurikulum berbasis kompetensi nasional dan internasional.

Langkah lainnya berupa fasilitas internet yang digunakan sebagai sarana belajar jarak jauh, sehingga unsur tatap muka dengan dosen pun sebagai salah satu metode belajarmengajar tradisional yang banyak kita kenal selama ini dihilangkan karena digantikan dengan rekaman pengajaran yang disimpan dalam bentuk file computer yang dimasukkan ke dalam CD atau flash disk dan dapat diputar 
di video televisi maupun telepon pintar dan dijadikan program unggulan PTS tersebut seperti Bina Nusantara atau Binus.

Selain itu komputer sebagai media alat bantu mengajar dijadikan sarana utama, sehingga suatu PTS berani menyatakan sebagai PTS komputer karena hampir semua kegiatan belajar mengajar di PTS tersebut berbasis komputer misalnya di Unikom maupun Gunadarma. Selain itu juga untuk bertahan mempertahankan para dosen tetap yang lamanya juga untuk menarik para dosen baru yang kompeten di bidangnya berbagai PTS di Jawa Barat dengan berusaha bersaing di bidang kesejahteraan dan pembinaan karir berupa peningkatan besaran kompensasi dan pembinaan karir yang semakin obyektif dan transparan bagi para dosennya.

\section{HASIL DAN PEMBAHASAN}

Gambaran umum kehidupan berbagai PTS di Indonesia yang terindikasi mengalami persaingan sengit dalam memperebutkan pasar calon mahasiswa barunya serta mengalami kekurangan dosentersebut sekarang terlihat jelas pada berbagai PTS khususnya yang ada di Jawa Barat, sebagai salah satu wilayah yang dekat dengan Ibukota, misalnya di Bogor dan sekitarnya terdapat satu PTN yaitu IPB yang termasuk salah satu PTN BHMN yang tadinya berbasis rumpun ilmu pertanian pada saat sumber keuangannya mengalir dari pemerintah tetapi begitu statusnya menjadi BHMN dengan cepat membuka persaingan di rumpun ilmu yang lain yang selama ini banyak diminati banyak calon mahasiswa seperti misalnya rumpun ilmu ekonomi.

Dampak dari adanya pembukaan program D3 dan S1 ekonomi di IPB disinyalir menyebabkan timbulnya fenomena penurunan jumlah mahasiswa di berbagai PTS di Bogor dan sekitarnya yang membuka program studi rumpun ilmu ekonomi seperti di UNB, STIE Pandu Madania, STIE Bina Niaga, STIE Kalpataru, Universitas Muhammadiyah Sukabumi, Universitas Suryakencana Cianjur, dan lain-lain. Kondisi inilah yang akhirnya menimbulkan terjadinya persaingan sengit antar PTStersebut untuk menarik calon mahasiswa di BogorRaya dan sekitarnya yang jumlahnya semakin berkurang karena diduga banyak tersedot oleh berbagai program studi baru di IPB tersebut. Kondisi seperti ini ternyata juga dialami di Priangan Timur dimana Unpad sebagai salah satu PTN terbesar di Priangan Timur juga membuka berbagai program studi yang dapat menampung mahasiswa dalam jumlah yang besar sehingga hal ini disinyalir menimbulkan persaingan sengit dengan PTS-PTS yang berlokasi di Priangan Timur seperti Universitas Garut, Universitas Galuh Ciamis, STEBIS Sumedang, Akademi Sekretari dan Manajemen Al Ma'soem, UNINUS, UNISBA, UNPAS, UNPAR, UNBAR, UTAMA, USB, UNJANI, STIE Yasa Anggana, STIE Cipasung, dll

Dalam rangka untuk menciptakan keunggulan kompetitifnya pada calon mahasiswa baru, sekarang banyak PTS di Jawa Barat ini melakukan beberapa program pemasaran bauran pemasaran jasa seperti yang dijelasan oleh Lupiyoadi dalam Manajemen Pemasaran Jasa (2001) yang inovatif dalam perkembangan industry jasa seperti melakukan ikatan kemitraan dengan beberapa sekolah menengah untuk mengarahkan para siswanya melanjutkan kuliah pada PT mereka, memberikan bonus pada guru yang berhasil mengarahkan para siswanya menuju pada PT mereka, dan memberikan ikatan beasiswa untuk siswa siswi terbaik suatu sekolah dan lain-lain.Semua program pemasaran PTS-PTS di Jawa Barat ini dilaksanakan dengan tujuan agar jumlah mahasiswa baru mereka bertambah, mempertahankan hubungan erat dengan fihak sekolah serta berbagai instansi atau lembaga, dan menjaga citra baik di hadapan pasarinput yaitupara siswa yang baru lulus sekolah menengah atas dan kejuruan ataupun para karyawan instansi dan perusahaan. Selain itu di pasar input yang lainnya berupa para dosen pengajarnya maka untuk mempertahankan para dosen lama sekaligus untuk menarik dosen baru terutama yang berkompetensi di bidang ilmu ekonomi akuntansi dan manajemen yang dirasakan 
jumlah dosennya sangat kurang di saat yang sama jumlah mahasiswanya sangat besar maka para beberapa pengelola PTS menawarkan kompensasi yang menarik dengan jenjang karir yang jelas serta penawaran pembiayaan sekolah lanjutan dengan program beasiswa yayasan disamping dana beasiswa dari pemerintah pusat dan daerah misalnya Ibnu Khaldun dan STIE Kesatuan Bogor yang jika dosennya melanjutkan sekolah maka beasiswanya dobel untuk Ibnu Khaldun mendapatkan dari yayasan sekaligus dari pemerintah pusat atau pun disuruh memilih apakah dari yayasan ataukah dari pemerintah pusat di STIE Kesatuan Bogor .

Program pemasaran yang dilaksanakan berbagai PTS di Jawa Barat khususnya di Priangan Timur dan Bogor Raya ini ditujukan untuk para dosennya tidak hanya yang bersifat penawaran program pemasaran secara umum menurut ilmu pemasaran tapi sudah khusus menukik pada program pemasaran yang bersifat eksistensi dari fungsi dan tugas PTS itu sendiri sebagai lembaga pendidikan yang bertugas meningkatkan dan mengembangkan tingkat pendidikan masyarakat dengan pelaksanaan kegiatan berbentuk Tridharma PT yang meliputi Pendidikan, Penelitian, dan Pengabdian Masyarakat.

Sehubungan dengan hal di atas makamenjadi menarik tentang usaha pemasaran beberapa PTS di Jawa Baratini khususnya kepada para dosenpengajar sebagai salah satu sumber daya yang diperlukan dalam proses operasional jasa mereka ini dengan mulai memfokuskan diri untuk menampilkan dan memromosikan aspek-aspek pemasaran jasa pendidikan yang sesuai standar akreditasi BAN berupa kegiatan Pendidikan, Penelitian, dan Pengabdian kepada Masyarakat, yang selama ini telah dilaksanakan di berbagai perguruan tinggi masing-masing yang pada khususnya diarahkan pada pengembangan dan pengelola kompetensi dosen di bidang pendidikan. Selain itu juga Pemerintah melalui Kemristek Dikti mulai melaksanakan program peningkatan kualitas PTN dan PTS di Indonesia melalui program pemeringkatan PTN dan PTS mulai tahun 2015 se Indonesia yang berjumlah kurang lebih 3320 PTN dan PTS, berdasarkan aturan UU dengan melaksanakan kegiatan pemeringkatan PT berdasarkan empat kriteria yaitu dilihat dari kualitas SDM, kualitas Manajemen, kualitas Kegiatan Kemahasiswaan dan kualitas Penelitian dan Publikasi Ilmiah. Hasil kriteria yang empat ini adalah output dari proses kualitas aktivitas yang bertumpu pada empat aspek penilaian Perguruan Tinggi ini yang menjadi dasar penilaian peringkat Perguruan Tinggi yang bersangkutan di Indonesia umumnya dan Priangan Timur serta Bogor Raya khususnya dan hasil pemeringkatannya berkaitan dengan kompetensi PTS pada pengembangan kompetensi para dosen yang dirasakan oleh para dosennya sendiri saat ini.

Selain itu berkaitan dengan era MEA atau Masyarakat Ekonomi ASEAN (MEA) maka berdasarkan sejarahnya Perhimpunan Bangsabangsa Asia Tenggara atau Association of Southeast Asian Nations (ASEAN) merupakan sebuah organisasi negara-negara di kawasan Asia Tenggara yang didirikan di Bangkok, Thailand, pada 8 Agustus 1967 berdasarkan Deklarasi Bangkok oleh lima negara yaitu Indonesia, Malaysia, Filipina, Singapura, dan Thailand. Junlah negara anggotra ASEAN sekarang mencapai 10 negara anggota. ASEAN ini secara keseluruhan mempunyai penduduk sebesar 600 juta orang dengan 250 juta orang penduduk indonesia dan komposisi penduduk berdasarkan status ekonominya yaitu penduduk miskinnya mencapai 15 persen, kelas menengahnya mencapai 37 persen dan orang kayanya mencapai 48 persennya dari jumlah total 600 juta orang tersebut yang kebanyakan menjadi penduduk di Singapura dan Malaysia serta Brunei Darussalam, Thailand dan Indonesia.

Tujuan dari pembentukan Komunitas ASEAN adalah untuk lebih mempererat integrasi ASEAN dalam menghadapi perkembangan konstelasi politik internasional. ASEAN menyadari sepenuhnya bahwa ASEAN perlu menyesuaikan cara pandangnya agar dapat lebih terbuka dalam menghadapi permasalahan-permasalahan internal dan eksternal. Dan hal ini juga diperkuat dengan 
adanya ASEAN Charter atau piagam ASEAN yang ditandatangani oleh hampir sepuluh pimpinan negara ASEAN pada tahun 2014 yang lalu.

Negara-negara ASEAN memproklamirkan pembentukan komunitas ASEAN (ASEAN Community) yang terdiri atas tiga pilar yaitu: Komunitas Keamanan ASEAN (ASEAN Security Community/ASC), Komunitas Ekonomi ASEAN (ASEAN Economic Community/AEC), dan Komunitas SosialBudaya ASEAN (ASEAN Socio-Cultural Community/ASCC). Tiga pilar pendukung tersebut akan menjadi paradigma baru yang akan menggerakkan kerjasama ASEAN ke arah sebuah komunitas dan identitas baru yang lebih mengikat dan dari ketiga pilar tersebut, Indonesia saat ini mengedepankan pembangunan komunitas ekonomi ASEAN/masyarakat Ekonomi ASEAN 2015 (ASEAN Economic Community/AEC). AEC 2015 akan diarahkan kepada pembentukan sebuah integrasi ekonomi kawasan dengan mengurangi biaya transaksi perdagangan, memperbaiki fasilitas perdagangan dan bisnis, serta meningkatkan daya saing sektor UMKM. Pemberlakuan AEC 2015 bertujuan untuk menciptakan pasar tunggal dan basis produksi yang stabil, makmur, berdaya saing tinggi, dan secara ekonomi terintegrasi dengan regulasi efektif untuk perdagangan dan investasi, yang di dalamnya terdapat arus bebas lalu lintas barang, jasa, investasi, dan modal serta difasilitasinya kebebasan pergerakan pelaku usaha dan tenaga kerja. Implementasi AEC 2015 akan berfokus pada 12 sektor prioritas, yang terdiri atas tujuh sektor barang (industri pertanian, peralatan elektonik, otomotif, perikanan, industri berbasis karet, industri berbasis kayu, dan tekstil) dan lima sektor jasa (transportasi udara, pelayanan kesehatan, pariwisata, logistik, dan industri teknologi informasi atau e-ASEAN). Untuk dapat memainkan peranan dalam AEC, diperlukan persiapan yang matang dengan memperhatikan peluang yang dimiliki dan tantangan yang dihadapi serta langkah strategi yang harus disiapkan(Sekretariat Negara, 2014)
Terlepas dari berita di atas, Indonesia saat ini memiliki posisi yang cukup meragukan (tidak baik, maupun buruk) jika dibandingkan dengan negara-negara ASEAN dari beberapa aspek perekonomian. Hingga saat ini Indonesia dikenal memiliki PDB terbesar seASEAN. Sejak tahun 2011 hingga saat ini Indonesia masuk kedalam 16 negara dengan pendapatan terbaik menurut PDB yaitu pada tahun 2014 sendiri Indonesia memiliki PDB sebesar 878 milyar US Dollar. Tetapi tingginya PDB Indonesia tidak sejalan positif dengan besarnya PDB per-kapita kita dimana dari 10 negara ASEAN Indonesia hanya menempati peringkat 5 , sedangkan 4 negara yang berada diatas Indonesia adalah, 1. Singapura (Besarnya PDB per-kapita USD \$51,162), 2. Brunei Darussalam (USD\$41,703), 3. Malaysia (USD\$10,304), 4.Thailand (USD\$10,304), (Rafdy Alwafi, kompasiana.com, 2014))Sedangkan jika kita melihat peringkat daya saing kita, menurut data yang dilansir oleh World Economic Forum (WEF) dalam The Global Competitiveness Report 2013-2014, Indonesia menempati peringkat 38 dari 148 Negara. Jika dibandingkan dengan negara-negara ASEAN, Indonesia menempati peringkat kelima di ASEAN dimana Empat negara yang berada di atas Indonesia ditempati oleh Singapura (2), Malaysia (24), Brunei Darussalam (26) dan Thailand (37). Dengan menggunakan indikator 12 pilar daya saing, yaitu institusi, infrastruktur, makroekonomi, kesehatan, pendidikan dasar, pendidikan tinggi, efisiensi pasar barang, efisiensi pasar tenaga kerja, pasar keuangan, kesiapan teknologi, besaran pasar, dan inovasi, Rafdy Alwafi, Kompasiana.com, 2014).

Seperti yang kita ketahui menurut data yang dilansir oleh World Economic Forum (WEF) dalam The Global Competitiveness Report 2013-2014 peringkat daya saing Indonesia menempati peringkat kelima di ASEAN dimana Empat negara yang berada di atas Indonesia ditempati oleh Singapura (2), Malaysia (24), Brunei Darussalam (26) dan Thailand (37). Singkatnya dari ke 12 Pilar yang merupakan indikator dari pengukuran 
tingkat daya saing tersebut, pilar ke-10 (ukuran pasar) memiliki peringkat terbaik yaitu memiliki peringkat 15 , dan pilar ke-7 (efisiensi pasar tenaga kerja) memiliki peringkat terendah yaitu memiliki peringkat 103 dari 148 Negara. Sehingga untuk menjadi Pemain Utama dalam masyarakat Ekonomi ASEAN (MEA) 2015 Indonesia harus berupaya untuk memperbaik kondisi perekonominya, seperti berupaya memperbaiki ke-12 pilar daya saing ekonomi khususnya efisiensi tenaga kerja sehingga bisa mengurangi ketergantungan mengimpor barang terhadap negara asing.

Memperhatikan berita dari Setneg dan Kompasiana.com di atas maka dapat diperkirakan bahwa pembentukan Komunitas Ekonomi ASEAN pada tahun 2015 dan kini menuju 2017 ini mempunyai dampak secara langsung maupun tidak langsung terhadap masyarakat Indonesia secara keseluruhan. Dampak yang terjadi ini bisa yang sifatnya negatif berupa pelemahan dan tantangan ataupun juga positif yaitu penguatan potensi dan keuntungan bagi masyarakat Indonesia.

Berdasarkan gambaran situasi perekonomian Indonesia saat ini maka beberapa potensi Indonesia untuk merebut persaingan di AEC 2015, antara lain:

1. Indonesia merupakan pasar potensial yang memiliki luas wilayah dan jumlah penduduk yang terbesar di kawasan $(40 \%$ dari total penduduk ASEAN).

2. Indonesia merupakan negara tujuan investor ASEAN. Proporsi investasi negara ASEAN di Indonesia mencapai $43 \%$ atau hampir tiga kali lebih tinggi dari rata-rata proporsi investasi negaranegara ASEAN di ASEAN yang hanya sebesar $15 \%$.

3. Indonesia berpeluang menjadi negara pengekspor, dimana nilai ekspor Indonesia ke intra-ASEAN hanya 18-19\% sedangkan ke luar ASEAN berkisar 80$82 \%$ dari total ekspornya, Hal ini berarti peluang untuk meningkatkan ekspor ke intra-ASEAN masih harus ditingkatkan agar laju peningkatan ekspor ke intra-
ASEAN berimbang dengan laju peningkatan impor dari intra-ASEAN.

4. Indonesia sebagai negara dengan jumlah populasi terbesar akan memperoleh keunggulan tersendiri, yang disebut dengan bonus demografi. Perbandingan jumlah penduduk produktif Indonesia dengan negara-negara ASEAN lain adalah 38:100, yang artinya bahwa setiap 100 penduduk ASEAN, 38 adalah warga negara Indonesia. Bonus ini diperkirakan masih bisa dinikmati setidaknya sampai dengan 2035, yang diharapkan dengan jumlah penduduk yang produktif akan mampu menopang pertumbuhan ekonomi dan peningkatan pendapatan per kapita penduduk Indonesia(P3DI, 2014)

Namun disamping keuntungan dan potensi Indonesia di atas, ada bentuk kelemahan yang mengancam indonesia pada saat MEA yang berlangsung sekarang ini yaitu:

1. Infrastruktur berdasarkan The Global Competitiveness Report 2013/2014 yang dibuat oleh World Economic Forum (WEF), daya saing Indonesia berada pada peringkat ke-38. Sementara itu kualitas infrastruktur Indonesia menempati peringkat ke-82 dari 148 negara atau berada pada peringkat ke-5 diantara negara-negara inti ASEAN. Hal ini menunjukkan bahwa infrastruktur Indonesia masih jauh tertinggal.

2. Indeks pembangunan manusia (HDI) merupakan suatu bentuk ringkasan pengukuran pembangunan manusia di setiap negara yang dilakukan oleh UNDP.Dalam HDI, pengukuran dilakukan terhadap rata-rata pencapaian suatu Negaradalam tiga dimensi dasar pembangunan manusia dalam bentuk (a) usia dan kesehatan hidup, yang diukur melalui harapan hidup saat lahir; (b) pengetahuan, diukur melalui tingkat melek huruf orang dewasa dan kombinasi rasio pendaftaran bruto pendidikan tingkat dasar, menengah dan lanjutan; (c) standar kehidupan 
yanglayak, yang diukur berdasarkan PDB per kapita dalam batasan paritas daya beli

3. Berdasarkan data Laporan Pembangunan Manusia UNDP 2007, Indeks Pembangunan Manusia Indonesia berada pada peringkat 107 dari 177 negara yang diukur oleh UNDP. Sementara itu, jika kita bandingkan dengan sepuluh negara ASEAN, Indonesia berada peringkat 7 di Asia Tenggara. Nilai HDI Indonesia padatahun 2005, dalam laporan tersebut adalah sebesar 0.728 , berada dalam kategori negara dengan pembangunan manusia menengah, satu kelompok dengan Thailand yang berada pada peringkat 78 di dunia dan 4 di ASEAN dengan nilai 0.781, diikuti Filipina pada peringkat 90 dunia dan 5 ASEAN dengan nilai 0.771 , serta Vietnam pada peringkat 105 dunia dan 6 ASEAN dengan nilai 0.733 .

4. Sementara itu, tiga negara ASEAN lainnya (Singapura, Brunei Darussalam dan Malaysia) masuk dalam kelompok negara dengan pembangunan manusia yang tinggi,di mana Singapura berada pada peringkat 25 dunia dan pertama ASEAN dengannilai HDI 0.922, diikuti Brunei peringkat 30 dunia dan kedua ASEAN dengan nilai0.894, disusul oleh Malaysia pada peringkat 63 dunia dan ketiga ASEAN dengannilai 0.811.Dalam kelompok negara-negara ASEAN, berdasarkan nilai HDI ini, Indonesia juga mengalami peningkatan posisi menduduki peringkat keenam dari sepuluh negara Asia Tenggara. Akan tetapi kualitas sumber daya manusia tetap tertinggal dari Singapura, Brunei Darussalam, Malaysia, Thailand dan Filipina. Bonus demografi yang dimiliki Indonesia, tidak akan memberikan keuntungan apa pun tanpa adanya perbaikan kualitas SDM. Data dari ASEAN Productivity Organization (APO) menunjukkan dari 1000 tenaga kerja Indonesia hanya ada sekitar 4,3\% yang terampil, sedangkan Filipina $8,3 \%$, Malaysia 32,6\%, dan Singapura 34,7\%,

5. Berdasarkan struktur pasar, tenaga kerja didominasi oleh pekerja lulusan SD $(80 \%)$ sementara lulusan Perguruan Tinggi hanya $7 \%$, dimana saat ini sebagian dunia kerja mensyaratkan lulusan Perguruan Tinggi. Hal ini sangat berbanding terbalik dengan Malaysia yang sebagian besar penduduknya lulusan S1. Sedangkan seperti yang kita ketahui menurutdata yang dilansir oleh World Economic Forum (WEF) dalam The Global Competitiveness Report 2013-2014 peringkat daya saing Indonesia menempati peringkat kelima di ASEAN dimana Empat negara yang berada di atas Indonesia ditempati oleh Singapura (2), Malaysia (24), Brunei Darussalam (26) dan Thailand (37). Singkatnya dari ke 12 Pilar yang merupakan indikator dari pengukuran tingkat daya saing tersebut, pilar ke-10 (ukuran pasar) memiliki peringkat terbaik yaitu memiliki peringkat 15 , dan pilar ke-7 (efisiensi pasar tenaga kerja) memiliki peringkat terendah yaitu memiliki peringkat 103 dari 148 Negara. Sehingga untuk menjadi Pemain Utama dalam masyarakat Ekonomi ASEAN (MEA) 2015 Indonesia harus berupaya untuk memperbaik kondisi perekonominya, seperti berupaya memperbaiki ke-12 pilar daya saing ekonomi khususnya efisiensi tenaga kerja sehingga bisa mengurangi ketergantungan mengimpor barang terhadap negara asing.

Melihat penjelasan di atas maka titik lemah utama Sistem Perekonomian Indonesia memasuki era AFTA tahun 2015 dalam lingkungan Masyarakat Ekonomi ASEAN ini adalah pada bidang SDMnya. Dan kelemahan SDM ini menjadi tinjauan utama yang perlu diperhatikan oleh pemerintah dan masyarakat Indonesia khususnya kalangan masyarakat perguruan tinggi yang tidak terkecuali 
mengalami fenomena masalah yang sama dimana jumlah SDM dosen yang professional dan berkompeten yang sangat kurang yang mempunyai komitmen untuk membantu pemerintah dalam usaha ikut mencerdaskan kehidupan bangsa ini ke depannya. Usaha meningkatkan kecerdasan bangsa ini diupayakan melalui peningkatan tingkat pendidikan masyarakat Indonesia dengan menyediakan program pendidikan level D3, S1, S2, dan S3 khususnya pada lingkup bidang ilmu ekonomi. Namun disadari karena kondisi persaingan sudah berubah yang tadinya pada dataran nasional sekarang meningkat menuju regional ASEAN maka tingkat penguasaan ilmu atau kompetensi para pengajarnya harus mendapat perhatian utama. Selain itu kurikulum dan fasilitas pendidikannya dan juga kegiatan Tridharma PT nya berupa Pendidikan, Penelitan, dan Pengabdian pada Masyarakat khususnya dalam lingkup kompetensi ilmu yang bernuansa nasional maupun internasional seperti ruang lingkup regional ASEAN ini yang mempunyai standar Internasional pula.

Indonesia mempunyai sejumlah 3485 PT dengan rincian 3385 PTS selain 100 PTN yang harus dipersiapkan menghadapi situasi persaingan regional MEA ini (Aptisi.org). Kalau tidak dipersiapkan secara matang maka tidak terbayangkan berapa banyak PTS Indonesia yang akan tersisih menghadapi era persaingan MEA yang diprediksi akan sangat ketat ini. Meningkatkan kualitas dan cakupan penelitian perguruan tinggi agar dapat memberikan saran kebijakan dan masukan kepada pemerintah dan swasta tentang langkah dan peluang yang dapat diraih oleh Indonesia di pasar ASEAN; atau tentang strategi negara ASEAN lain yang harus diwaspadai oleh Indonesia. Selain itu juga kegiatan PTS yang lain yang dapat dilakukan adalah Kegiatan Tridharma PT berdasarkan UU RI No 12 Tahun 2012 point 9 berupa kegiatan Pendidikan, Penelitian, dan Pengabdian kepada Masyarakat misalnya:

1. Memberikan edukasi kepada masyarakat sekitar tentang AEC 2015, yang dapat diselipkan dalam program pengabdian masyarakat atau kuliah kerja nyata.

2. Memperkuat Kapasitas Kelembagaan Perguruan Tinggi Menghadapi AEC, bukan saja pada aturan-aturan main yang ada, namun pada organisasi secara keseluruhan. Kementerian Pendidikan dan Kebudayaan sudah sejak lama memberikan dorongan pada upaya penguatan itu, yang diintroduksi lewat berbagai aktivitas untuk mengarahkan pada Good University Governance atau Tata kelola (Tata Pamong) Perguruan Tinggi yang Baik.

3. Selain itu beberapa langkah yang lain adalah melakukan penjaminan mutu dan akreditasi sesuai standar nasional dan internasional.

4. Dalam mengembangkan kurikulum, selain memasukkan pendidikan soft skill dan entrepreneurship, serta sertifikasi, juga orientasi kepada Kerangka Kualifikasi Nasional Indonesia (KKNI) dan Kerangka Kualifikasi Regional (KKR) merupakan suatu keharusan. Oleh karena itu sosialisasi, khususnya tentang KKNI harus lebih ditingkatkan.

5. Kerjasama-kerjasama baik dengan sesama perguruan tinggi dalam negeri maupun dengan perguruan tinggi luar negeri, khususnya perguruan tinggi ASEAN sangat perlu dalam rangka meningkatkan kapasitas perguruan tinggi kita, baik melalui proyek-proyek penelitian bersama. Joint seminar, menghadirkan dan menjadi dosen tamu internasional, pertukaran mahasiswa, mutual recognition arrangemment (MRA) dan sebagainya, (Aptisi.Org, 2014)

Sisi lain dari muramnya kondisi SDM di Indonesia ini juga terdapat di Perguruan Tinggi khususnya Perguruan Tinggi Swasta di Indonesia umumnya dan Jawa Barat pada khususnya karena banyak para dosen pengajarnya kurang mempunyai kualifikasi yang memadai untuk bisa mengajar di Perguruan Tinggi baik dilihat dari segi level 
pendidikan, linieritas tingkat keilmuan hingga tingkat kompensasi yang masih di bawah standar kesejahteraan yang layak yang tentunya sangat berbanding terbalik dengan tuntutan tinggi para pengelola PTS terhadap tingkat kompetensi para dosen yang diharapkan yang bekerja di lembaganya masing-masing.

Maka berdasarkan survey pendahuluan dengan menanyakan pada 30 orang dosen diketahui terdapat fenomena permasalahan dimana para dosen PTS di Priangan Timur dan Bogor Raya menyatakan masing-masing secara relatif belum saling mengetahui dan mengenal nama dan simbol PTS-PTS yang secara umum seharusnya dapat dilihat dari berbagai aktivitas kegiatan pelaksanaan produk Tridarma Perguruan Tinggi PTS-PTS yang bersangkutan selain PTS yang ada tempat mereka bekerja saat ini, selain itu ada beberapa PTS diketahui bercitra kurang baik dengan adanya kasus kriminal para mahasiswanya, tidak mengetahui visi misi berbagai PTS tersebut dalam menyelenggarakan pendidikan, tidak pernah mendengar hasil kegiatan penelitian para dosen dan mahasiswanya, serta tidak mendengar kiprah para alumninya dalam membangun negara dan bangsa ini. Mereka kenal hanya kegiatan pendidikan di PTN yaitu IPB dan Unpad sehingga secara keseluruhan banyak para dosen lebih mengenal IPB atau Unpad dibandingkan sesama PTS yang lainnya.

Fenomena permasalahan yang lainnya yaitu berupa hasil pemeringkatan PTS di Bogor Raya khususnya diperluas umumnya hingga ke Priangan Timur yang masih belum meyakinkan menurut Kemristek Dikti dimana Universitas Djuanda urutan 73, STIE Kesatuan urutan 195, Universitas Ibnu Khaldun urutan 314, Universitas Pakuan urutan 682 dan seterusnya (Kemristek Dikti, 2015) yang mana hasil pemeringkatan PTS di Bogor Raya serta Priangan Timur tersebut belum mencapai urutan Top Forty atau urutan 50 besar terbaik sehingga belum mendukung kepada penguatan merek yang baik.
Dan fenomena masalah yang lainnya khusus yang menyangkut perguruan tinggi (PT) di tingkat ASEAN, berdasarkan informasi yang ada kualitas PT kita khusunya PTS masih jauh tertinggal, baik dilihat dari pemeringkatan seperti Webometric, QS Star, masih belum ada yang menembus level 100 dunia. Yang mampu dilakukan PT indonesia adalah menembus level 100 PT terbaik se ASEAN dan yang menembus rangking 10 besar itupun baru dicapai UGM pada peringkat 7 dan UI pada peringkat 8 yang notabene adalah PTN bukan PTS (education.com, 2014). Hal ini merefleksikan rendahnya produktivitas dan kualitas penelitian dan publikasi para dosen di Indonesia khususnya para dosen PTS (Aptisi.org, 2014).

Maka berbagai fakta di atas berdasarkan hasil surveymembuat persepsi bahwa Kekuatan Bersaing serta Asosiasi Merek berbagai PTS di Jawa Barat khususnya di Priangan Timur dan Bogor Raya masih sangat rendah dibandingkan kekuatan bersaing PT di ASEAN dan dunia.Selain itu merujuk pada fakta di atas maka solusi permasalahannya terletak pada belum profesionalnya para dosen PT Indonesia di Jawa Barat dalam mengelola dunia pendidikan di Jawa Barat seperti yang dikemukakan Dirjen Sumber Daya Penelitian Kemristekdikti Prof Ali Ghufron Mukti pada acara halal bihalal Civitas Academica UIN Syarif Hidayatullah Jakarta pada bulan Agustus 2017 yang menyebutkan bahwa posisi bersaing yang rendah dari berbagai PT Indonesia disebabkan oleh masih rendahnya intensitas dan kualitas hasil penelitian para dosen PTN dan PTS di Indonesia terutama yang tercatat pada jurnal penelitian internasional Scopus dan lainnya.

Hal ini menyadarkan para pimpinan Kemristekdikti yang bertanggung jawab terhadap kemajuan PT di Indonesia ini untuk semakin mendorong para dosen PT di Indonesia khususnya Jawa Barat untuk semakin giat melaksanakan kegiatan Tridharma PT khususnya pada aspek penelitian yang dipublikasikan secara internasional. Dan Hal ini juga ditekankan kembali oleh Koordinator Kopertis Wilayah 
IV Jabar dan Banten yaitu Prof Umar Suherman yang kembali menegaskan tentang lemahnya daya saing berbagai PT di Jawa Barat di tingkat internasional karena kurangnya penelitian yang dipublikasi secara internasional ini dari para dosen PTN dan PTS di Jawa Barat pada acara Tridharma Penelitian di Universitas Djuanda Jawa Barat pada bulan Agustus 2017.

Menyitir pendapat para tokoh yang bertanggung jawab secara langsung maupun tidak langsung terhadap kemajuan Perguruan Tinggi di Indonesia ini dan Jawa Barat pada khususnya maka dapat disimpulkan bahwa kurang bisa bersaingnya berbagai Perguruan Tinggi Negeri dan Swasta di Indonesia dan Jawa Barat pada khususnya pada level persaingan internasional lebih banyak diakibatkan oleh kurangnya budaya penelitian dan tidak terpublikasikannya hasil penelitian para dosen di Jawa Barat pada berbagai jurnal internasional yang bereputasi dunia seperti Scopus dan lain-lain. Maka solusi permasalahan rendahnya posisi bersaing di tingkat ASEAN dan MEA dari berbagai PT di Jawa Barat ini sebetulnya akhirnya dapat diketahui yaitu akibat kurangnya budaya penelitian dan rendahnya kesadaran untuk banyak menulis serta belum adanya kesadaran

untuk mempublikasikan hasil penelitian para dosen ini di jurnal penelitian yang bereputasi dunia saat ini yang mengakibatkan rendahnya daya saing dan posisi rangking berbagai PT di Indonesia dan Jawa Barat di tataran ASEAN, Asia dan Dunia.

\section{KESIMPULAN DAN IMPLIKASI}

Sebagai penutup maka dengan diketahuinya sumber permasalahan PT di Indonesia yang berposisi rendah dalam rangking PT dunia akibat dari kurangnya budaya menulis dan penelitian serta rendahnya tingkat kesadaran para dosennya untuk mempublikasikan pada berbagai jurnal internasional bereputasi seperti Scopus ini maka diharapkan para dosen PT di Indonesia dan Jawa Barat pada khususnya untuk semakin meningkatkan budaya menulis dan aktif dalam berbagai kegiatan penelitian sebagai peran serta para dosen dalam kegiatan Tridharma PT dan sumbangsih para dosen dalam usaha ikut meningkatkan posisi tawar dan PT Indonesia dan Jawa Barat pada khususnya dalam hal daya saing SDM Indonesia dalam menghadapi persaingan SDM tingkat Dunia.

\section{DAFTAR PUSTAKA}

Aptisi.org, 2014, Produktivitas Perguruan Tinggi

Alma, Buchary. 2003. Pemasaran Stratejik Jasa Pendidikan, Alfabeta, Bandung.

Alwafi, Rafdy,2014, Kompasiana.com,

Bitner, M.J, Zeithaml, V, 2003, Service Marketing, Tata. Mc Graw Hill, New Delhi

Gunawan, Rachmat, 2008, Pengaruh Pelatihan dan Kompensasi terhadap kinerja SDM Unit Pemasaran PTS Berfakultas Ekononomi di Bogor ,PHK A2 Manajemen, Kemristekdikti, Jakarta

Gunawan, Rachmat, 2013, Pengaruh Tridharma PT terhadap Kekuatan Merek PTS Berfakultas Ekonomi di Bogor, Penelitian Dosen Pemula, Kemristekdikti, Jakarta

Lupiyoadi, Rambat, 2001, Manajemen Pemasaran Jasa, Salemba Empat, Jakarta

Madri, M, 2016, Visual Brand Identity, diskusi blog

Sekretariat Negara, 2014, Masyarakat Ekonomi ASEAN

Pemeringkatan PT, 2015, PermenristekDikti no 15 , KemristekDikti

Undang-undang No. 12 Tahun 2012 tentang Pendidikan Tinggi. 